móveis, utensílios e documentos e um dossiê sobre o turismo praticado hoje nessas fazendas. A partir do material coletado em algumas delas será organizado um livro com receitas típicas das fazendas paulistas.

PATRIMÔNIO IMATERIAL A maioria das 17 fazendas paulistas que fizeram parte do projeto Fazendas Históricas Paulistas arrendou suas terras para plantações intensivas de cana ou laranja, em um modelo de agronegócio altamente mecanizado, totalmente diferente daquele vivido pelas fazendas em seus tempos áureos. Essas propriedades passam a ter apenas os prédios históricos e uma pequena área de entorno. $\mathrm{O}$ modelo de agronegócio vigente impõe uma nova dinâmica social nas fazendas históricas, que elimina as festas, as celebrações religiosas, toda uma cultura rural deixa de existir porque a comunidade que dava sentido a essa vida migrou para a cidade.

Esse conjunto de práticas compreende o chamado patrimônio intangível, termo cunhado para distinguir essa herança do patrimônio arquitetônico ou natural. "O projeto nas fazendas históricas paulistas tem se preocupado em captar esse patrimônio imaterial, ainda existente no meio rural paulista", conta a socióloga Olga von Simson, da Unicamp, que coordena as pesquisas nessa área. "Trabalhamos com a memória dos atores sociais que viveram na fazenda, no auge de sua atividade econômica e social para reconstruirmos e registrarmos a riqueza que esse patrimônio imaterial teve no passado", completa. Diversos elementos aparecem no contato com essas pessoas que viveram por muitos anos no meio rural, segundo a pesquisadora. "Fica clara a função dos gêneros naquelas comunidades: o homem ligado ao trabalho na terra, ao esforço da produção e a figura feminina ligada ao cuidado, seja no preparo dos alimentos, dos remédios e no cuidado da casa", exemplifica a pesquisadora. Das entrevistas com as mulheres surgem lembranças de músicas, novenas, das festas para os santos padroeiros, superstições para fazer chover, as sortes para achar marido, segredos da culinária, receitas de remédios à base de plantas.

TURISMO COM ALMA Com a migração para a cidade, essas fazendas, suas casas, equipamentos, jardins, acabam se transformando em espaços subocupados já que os novos modelos de atividade econômica a que elas se dedicam e os novos modelos familiares não dão conta de ocupar as imensas salas, os quartos, a grande cozinha. "Essa memória que tentamos reconstruir permite colocar alma nesses espaços, antes plenamente ocupados, mas que hoje estão esvaziados", acredita Olga. "A ideia é se valer desse conhecimento e tentar traduzi-lo em estratégias de divulgação da vida rural antiga para o turista", complementa. Algumas fazendas já têm aproveitamento empresarial, são hotéis-fazen$\mathrm{da}$, especializadas em cavalgadas, ou já recebem grupos de turistas para visitas de um dia. Outras praticam um turismo mais simples, recebendo famílias para o turismo chamado de habitação, quando as pessoas ficam hospedadas na fazenda participando das atividades cotidianas.

Patrícia Mariuzzo
FICÇÃO CIENTÍFICA

Cinema e LITERATURA

\section{A SERVIÇO DA CIÊNCIA}

"A imaginação é mais importante que o conhecimento", pois não tem fronteiras, é ilimitada, argumentava Albert Einstein. Esse poder imaginativo o físico alemão certamente usou para elaborar teorias que o alçaram para a história. Sua teoria da relatividade, grande avanço para a ciência, inspirou obras ficcionais que povoaram a mente de diretores de cinema, roteiristas e escritores. Exemplo clássico é a espaçonave Enterprise, da série Jornada nas estrelas (Star Trek), que começou a ser exibida no início da década de 1960. A série lançou ideias que estão até hoje no imaginário das pessoas, como vida alienígena inteligente ou atalhos no espaço-tempo. O caminho que leva especulações científicas à ficção pode ser considerado, porém, uma via de mão dupla: criações ficcionais também servem de inspiração para cientistas na produção de novas tecnologias. No livro " $A$ fisica de Jornada nas estrelas" (1996), o cosmólogo e astrofísico Lawrence M. Krauss reflete sobre "os desafios que teriam que ser enfrentados [na vida real] ao conceber a tecnologia da ficção" como, por exemplo, o universo ficcional do filme, que propõe inclusive o teletransporte. $\mathrm{Na}$ introdução da obra, o célebre físico britânico Stephen Hawking exalta a 

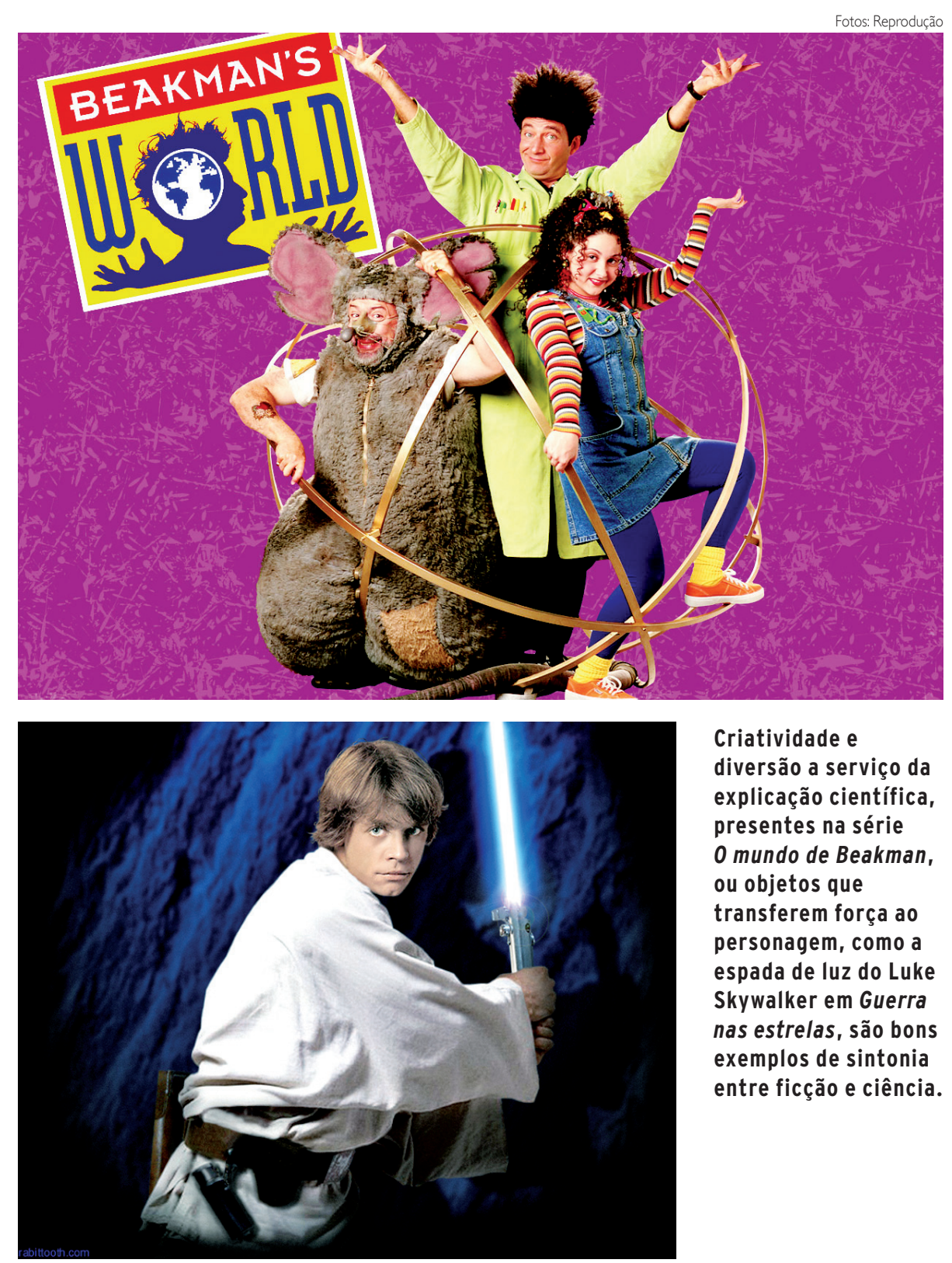

importância da ficção, pois ela é capaz de "expandir a imaginação humana", além da relevância de se estudar obras ficcionais, uma vez que "a ficção científica de hoje frequentemente é o fato científico de amanhā".

VERNEESANTOSDUMONT Essa conversa entre ficção científica e o fato científico comprovado por metodologias e experimentos, ocorre há bastante
Criatividade e diversão a serviço da explicação científica, presentes na série 0 mundo de Beakman, ou objetos que transferem força ao personagem, como a espada de luz do Luke Skywalker em Guerra nas estrelas, são bons exemplos de sintonia entre ficção e ciência.

adoras foi apoiada nas obras de Júlio Verne (1828-1905), que deram asas à sua imaginação. O escritor francês já havia inspirado também outros ficcionistas de seu tempo, como o compatriota George Méliès (1861-1938), considerado o pai dos efeitos especiais, que produziu o primeiro filme de ficção científica, Viagem à lua (1902), baseado no livro Da terra à lua, de 1865. Ambas as obras surpreenderam a sociedade com algo inatingível àquela época, profetizando o que ocorreria somente em 1969 - o homem em solo lunar. Usando o conhecimento do século XIX (Verne tinha amigos cientistas e engenheiros, e lia vários jornais para familiarizar-se com os avanços científicos) aliado à sua fértil criatividade, o escritor conseguiu idealizar viagens tripuladas ao espaço, algo impensável na época.

Vários outros presságios e constructos científicos antevistos a partir do cinema e da literatura de ficção podem ser ilustrados com obras. O próprio Júlio Verne em Robur, o conquistador (1886) previu um veículo voador em detalhes que se assemelhavam muito ao helicóptero, quando nem o avião existia. No livro Admirável mundo novo (Aldous Huxley, 1932) há várias ideias consideradas fantasiosas na data em que foi lançado, dentre as quais a geração de bebês em laboratório, o que viria a acontecer 46 anos depois, em 1978. E quem não enxerga semelhança entre a força mental com que personagens do filme Guerra nas estrelas (o primeiro filme data de 1977) movimentam objetos usando telepatia com os recentes experimentos do neurocientista brasileiro Miguel 
Nicolelis, que faz braços robóticos se moverem à distância a partir de estímulos elétricos cerebrais?

UMA QUESTÃO DE EDUCAÇÃO Mas não é só com previsões e especulações que a ciência se nutre da ficção científica. Pesquisas apontam que filmes dessa modalidade têm ajudado estudantes a entender melhor conceitos científicos. De acordo com Aguinaldo Robinson de Souza, professor do Departamento de Química da Unesp de Bauru, "o problema que se vê no processo de ensino nas escolas é que falta motivação para os alunos nas aulas de ciência”. Para ele, o ambiente de diversão criado pelos filmes de ficção é desencadeador de curiosidades e, assim, os estudantes começam a elaborar questões e buscar respostas. "Os alunos sentem-se mais à vontade num ambiente lúdico”, explica Aguinaldo, que também é orientador no Programa de Pós-Graduação em Educação para a Ciência, um dos pioneiros no Brasil. Em um de seus trabalhos, usou como ferramenta de ensino o filme Parque dos dinossauros (Jurassic Park) que descreve como cientistas manipularam DNA de sangue contido no tubo digestivo de pernilongos (preservados por milhóes de anos na seiva de uma árvore) para trazer dinossauros novamente à existência. Em sala de aula, pode-se perguntar "se é possível trazer um animal extinto à vida ou questionar se a lógica usada pelos cientistas do filme é correta,", completa o professor ao lembrar que o material genético de mamute (animal extinto há milhares de anos) já foi isolado e decifrado recentemente.
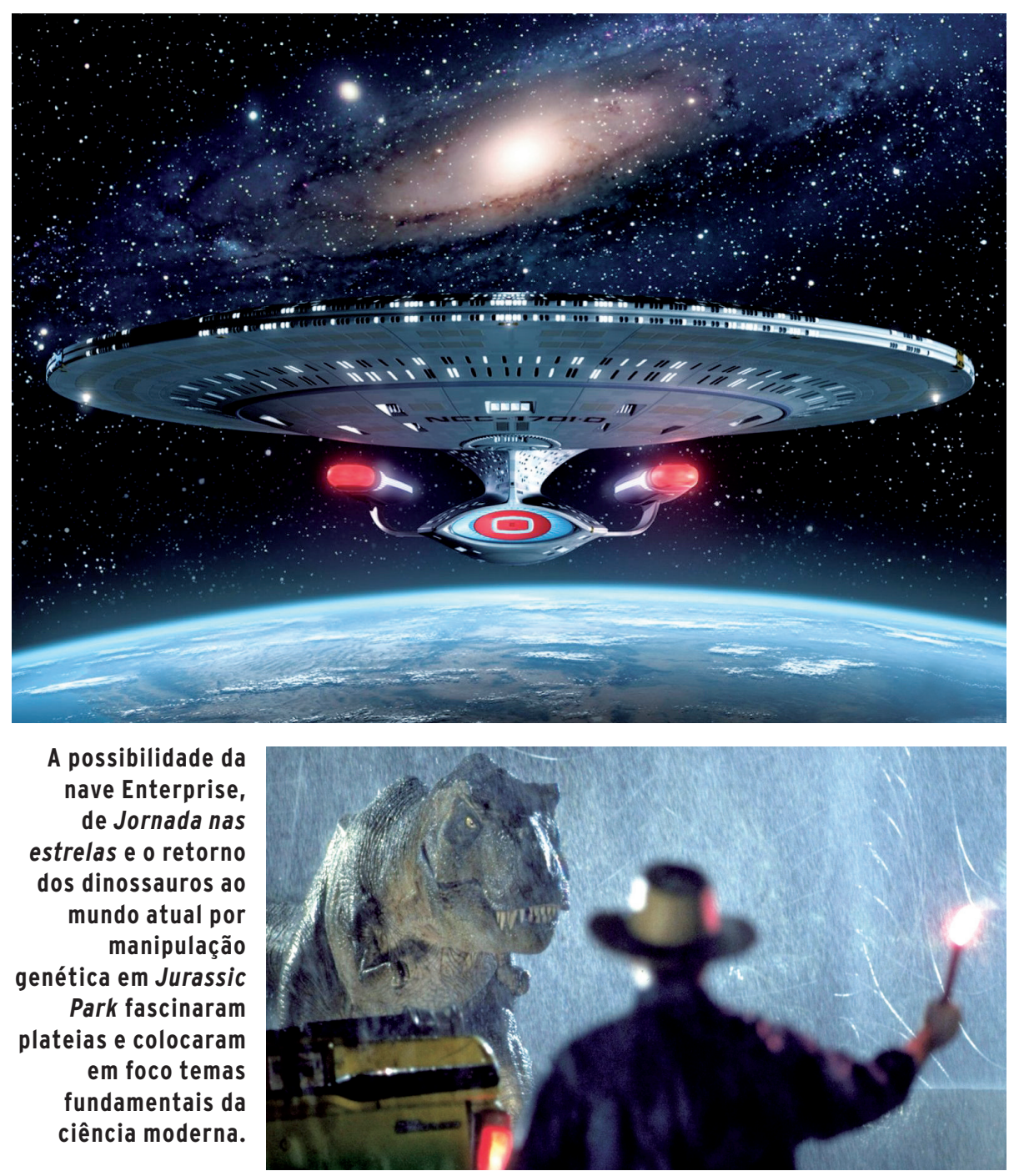

FICÇÃO E DIVULGAÇÃO DA CIÊNCIA Nos Estados Unidos, a criação de obras de ficção é coisa séria. Tanto que na Universidade do Kansas criou-se o Centro para Estudos de Ficção Científica, que promove cursos intensivos de como escrever estórias ficcionais. $\mathrm{O}$ astrônomo e cientista Carl Sagan (1934-96), um dos maiores divulgadores científicos de todos os tempos, deixou um legado de registros científicos filmados e escritos, como a série Cosmos, do começo dos anos 1980, e Contato, publicado postumamente, em 1997.
O modo fácil como explicava descobertas e fenômenos da astronomia, com recursos ficcionais, "certamente influenciou geraçôes na carreira científica", conta Wilson Roberto Pereira Júnior, integrante do grupo Ciência em Show e fã do programa $O$ mundo de Beakman, que atraiu muitas crianças e adolescentes para a frente da televisão na década de 1980 por causa dos incríveis experimentos que esclareciam muitos fenômenos.

Daniel Blasioli Dentillo 